\title{
ASSESSMENT OF MALIR RIVER WATER QUALITY AND IT SUITABILITY FOR IRRIGATION PURPOSES
}

\author{
MUHAMMAD SALEEM ${ }^{* 1}$

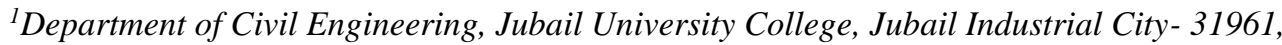 \\ Saudi Arabia
}

\begin{abstract}
Malir river, which is passing through industrial area of mega city Karachi is assessed for the suitability of its water for irrigation purposes. It was found that the concentration of studied metals is a function of position and season. Most of the pollutants are within the limits provided by national and international standards however, nickel was above the allowable limit for irrigation water quality $(1000 \mu \mathrm{g} / \mathrm{L})$ which is probably attributed to the discharge of effluent from vegetable-ghee manufacturing factories working in the vicinity. The overall suitability of Malir river based on EC, TDS and SAR is ranked'Permissible' for irrigation.
\end{abstract}

Keywords: river water quality, trace metals, environmental protection, industrial effluent

\section{INTRODUCTION}

Urbanization is one of the important factors for the socio-economic growth of a country. However, rapid industrialization and urbanization due to increasing population results in social, economical and political problems, which pose significant adverse effects on the quality of life [1]. Water bodies including lakes, ponds, rivers and coastal waters are seriously contaminated. To date the behavior and fate of various organic and inorganic contaminants including metals are poorly understood whether they are in soils, surface or ground waters. Generally, surface water such as rivers are recipient of organic and inorganic waste from domestic, commercial and agricultural runoff [2]. Worldwide the contamination of surface water particularly with metals is increasing with alarming rate. Increase of metal concentration is mainly intuitive from anthropogenic sources such as industrial, agricultural and urban activities [3].

The population of Pakistan was more than 144 million and was projected to reach 260 million by year 2050 . Furthermore, the per capita consumption of water in Pakistan is the highest in the region and the 14th highest in the world due to poor water management strategies [4]. The economy of Pakistan typically rely on agriculture however; current priority of Pakistan government is to develop industrial sector. Karachi is an industrial mega city of Pakistan. There are many chemical, beverages, automobile, food packaging, soap, textile, paint and other industries in and around the Korangi Industrial Trade Estate (KITE) of Karachi city. The effluent generated by these industries generally discharged without treatment to Malir river, which is polluting the water to an alarming level [5].

The basin of Malir River is situated between $24^{\circ} 45^{\prime} \mathrm{N}$ to $25^{\circ} \mathrm{N}$ Lat. and $67^{\circ} 13^{\prime} \mathrm{E}$ to $67^{\circ} 22^{\prime} \mathrm{E}$ Long, with a drainage area of $1520 \mathrm{sq}$. km. A major part of its basin is occupied by alluvial of Malir River. Malir River is a perennial river which carries the discharge of untreated wastewater and industrial effluents within its limits through its

\footnotetext{
* Corresponding author, email: saleemm@ucj.edu.sa

(C) 2020 Alma Mater Publishing House
} 
basin into the Arabian Sea [6, 7]. The objectives of the present study was three fold; i) get the information about the extent of metal pollution in the Malir River ii) evaluate the spatial distribution of metals in the up and downstream of the river reach and iii) obtain the baseline data for further action by authorities for mitigation or possible reuse. The information reported in this paper will help government and non-government water treatment plant authorities by giving data about the current status of water body. The findings will not only provide valuable facts on the environmental quality of Malir River, but also provide a scientific perception of the environmental effects of trace metals so that further regulatory and scientific attention can be drawn to the concern.

\section{MATERIALS AND METHODS}

\subsection{Sampling locations}

The reliability of a sample analysis mainly depends on the location from where sample is collected. A representative sample should be one, which contain essentially the same constituents as the location from which it is collected. Therefore, selection of appropriate location is vital for realistic results [8]. Therefore, selection of sites was done based on:

1. The pollution level within domestic area to evaluate the overall quality of the Malir river water before entering the industrial area.

2. Locations where effluents from industrial and domestic sources are being discharged.

Grab samples were collected from four predetermined positions at Malir river as shown in Figure 1. Samples were collected during period of June 2017 to April 2018 (at a frequency of every alternate month) to see the special and temporal seasonal variations in the river water quality. River carries wastewater discharged from various industrial and domestic sources of KITE and discharging into the Arabia Sea. As shown in Figure 1 two sites locating at upstream named Motorway M-9 intersection (25003'13.14"N 67041'05.98"E) and Noor Muhammad Goth (25003'38.77"N 67041'05.39"E)), and two sites locating at downstream were Allahwala Town Sector A (240 82’77.16"N 670 09²2.76"E), and DHA Phase 7-Ext (24081’83.67"N 670 08`62.96"E).

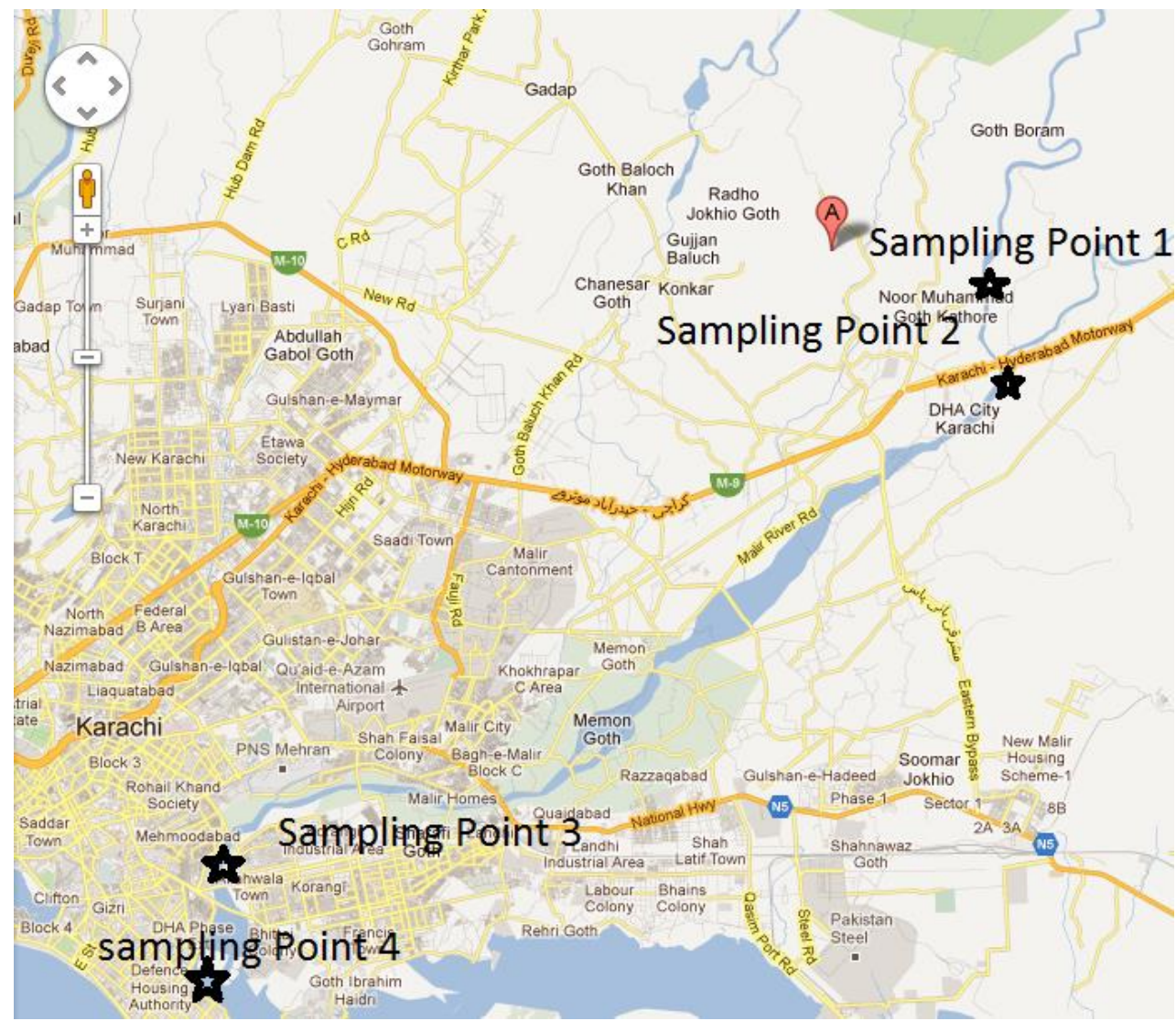

Fig. 1. Study area and location of sampling points at Malir river [9]. 


\subsection{Sample collection and Analysis}

To evaluate the magnitude of metal contamination in the Malir river water samples were collected in one liter white polyethylene plastic bottles which were pre-cleaned with distilled water than $20 \%$ diluted $\mathrm{HNO}_{3}$ followed by washing with tap water. At the time of sample collection, bottles were first rinsed with the river water and than grab sample were collected. These samples were transported to the "Chemical Analysis" laboratory at Karachi Institute of Power Engineering, Karachi as quick as possible. Concentrated $\mathrm{HNO}_{3}$ was used to acidify the samples up to $\mathrm{pH}<2.0$ and kept refrigerated at $4{ }^{\circ} \mathrm{C}$ and transported to laboratory for analysis. The metal analysis was done by Atomic Absorption Spectrophotometry (Perkin-Elmer Spectrophotometer Model 460) following the procedures delineated in Standards methods for the examination of water and wastewater [10].

Total dissolved solids (TDS), and Electrical conductivity (EC) has great importance if water need to be use for irrigation purpose. If the values of EC and TDS are high, it may degrade the soil and create significant irrigation problem. During the laboratory analysis, about $100 \mathrm{~mL}$ random water sample from each sampling points was collected to determine TDS by gravimetric method and EC was measure by EC/TDS meter (HACH/ 51800-10). Parameters such as $\mathrm{Na}^{+}, \mathrm{Ca}^{2+}, \mathrm{Mg}^{2+}$ also measured by Benchtop Ion Specific Meter (Orion Versa Star Pro pH/ISE, VSTAR40 series). Later, SAR calculated utilizing the values of $\mathrm{Na}^{+}, \mathrm{Ca}^{2+}, \mathrm{Mg}^{2+}$ found in the samples using the equation of Chang et al. [11].

\section{RESULTS AND DISCUSSION}

Concentration of some studied metals present at all sampling points during study period (in different seasons) is depicted in Figure 2. Range of the values (minimum-maximum) obtained during study period from all sampling points is reported in Table 1. A comparison of results obtained in present study with the results of water quality of various rivers in the world also presented in Table1. A comparison of obtained values during current study with the allowable limits for domestic use and irrigation water quality given by World Health Organization (WHO), US Environmental Protection Agency (US-EPA) and National Environmental Quality Standards (NEQS) by Pakistan Environmental Protection Council [12-14] is presented in Table 2.

\subsection{Concentration of studied metals at all sampling points}

In the following section results obtained during present study are discussed in detail:

Arsenic: It is reported that any water having concentration of arsenic above permeable limits can cause skin, and bladder as well as cardiovascular disease [15]. Concentration of arsenic obtained during study period was between $0.25-5.15 \mu \mathrm{g} / \mathrm{L}$ and maximum value of arsenic $(5.15 \mu \mathrm{g} / \mathrm{L})$ was found in June at sampling point 3 (Allahwala Town). The maximum permissible level of NEQS is $1000 \mu \mathrm{g} / \mathrm{L}$ therefore; concentration of arsenic in the Malir river is well below the allowable limit (NEQS). Similarly permissible limit provided by the, US-EPA and WHO shown in Table 2 are $10 \mu \mathrm{g} / \mathrm{L}$ which is still safe [12-14].

Iron: It was found that concentration of iron is high at all studied locations during study period. The concentration of iron was relatively high in June as compared to in other months (rage from $225.3-521.5 \mu \mathrm{g} / \mathrm{L}$ ). Where as in Indus river, Pakistan maximum concentration was only $154 \mu \mathrm{g} / \mathrm{L}$ [5]. Results in Table 1 shows that the concentration of iron in the Malir river is lower than Ganga river, India [16] and Yangtze river, China [17] and higher than Mississippi river, USA [18], Balu river, Bangladesh [19] and Po river, Italy [20] as shown in Table 3. The high concentration of iron in the Malir River may be attributed to the discharge of concentrated effluent from pipe manufacturing industries, leather tanneries, textile factories and various chemical industries along the river stretch. As shown in Table2 the concentration of iron exceeded the allowable limits of iron given by WHO, and US-EPA in river water that is $300 \mu \mathrm{g} / \mathrm{L}[12,13]$. However, it is below NEQS, Pakistan standards of $800 \mu \mathrm{g} / \mathrm{L}$ therefore, water could be utilized for irrigation purposes. However, it is necessary to treat the water before any domestic use, which is not safe for public health and environment [14].

Lead: During study period the concentration of lead found to be consistently high as compared to the allowable limits given by US-EPA $(15 \mu \mathrm{g} / \mathrm{L})$ however, it is within the limits of NEQS and WHO standard $(500 \mu \mathrm{g} / \mathrm{L}, 50$ $\mu \mathrm{g} / \mathrm{L}$ respectively). Highest concentration of lead was found as $38.04 \mu \mathrm{g} / \mathrm{L}$ at sampling point 3 (Allahwala Town) during June probably due to non point source. In previous study on Indus river, Pakistan carried out by Jaleel and coworkers concentration of lead was found up to $160 \mu \mathrm{g} / \mathrm{L}$ [5]. Comparison of other river waters quality presented in Table1 shows that the concentration of lead is below the allowable limits provided by WHO and NEQS, Pakistan. Results of present study show that although the level of lead is below WHO and NEQS limits it 
is above US-EPA therefore water may be harmful for human health and for aquatic life and should be use with caution.

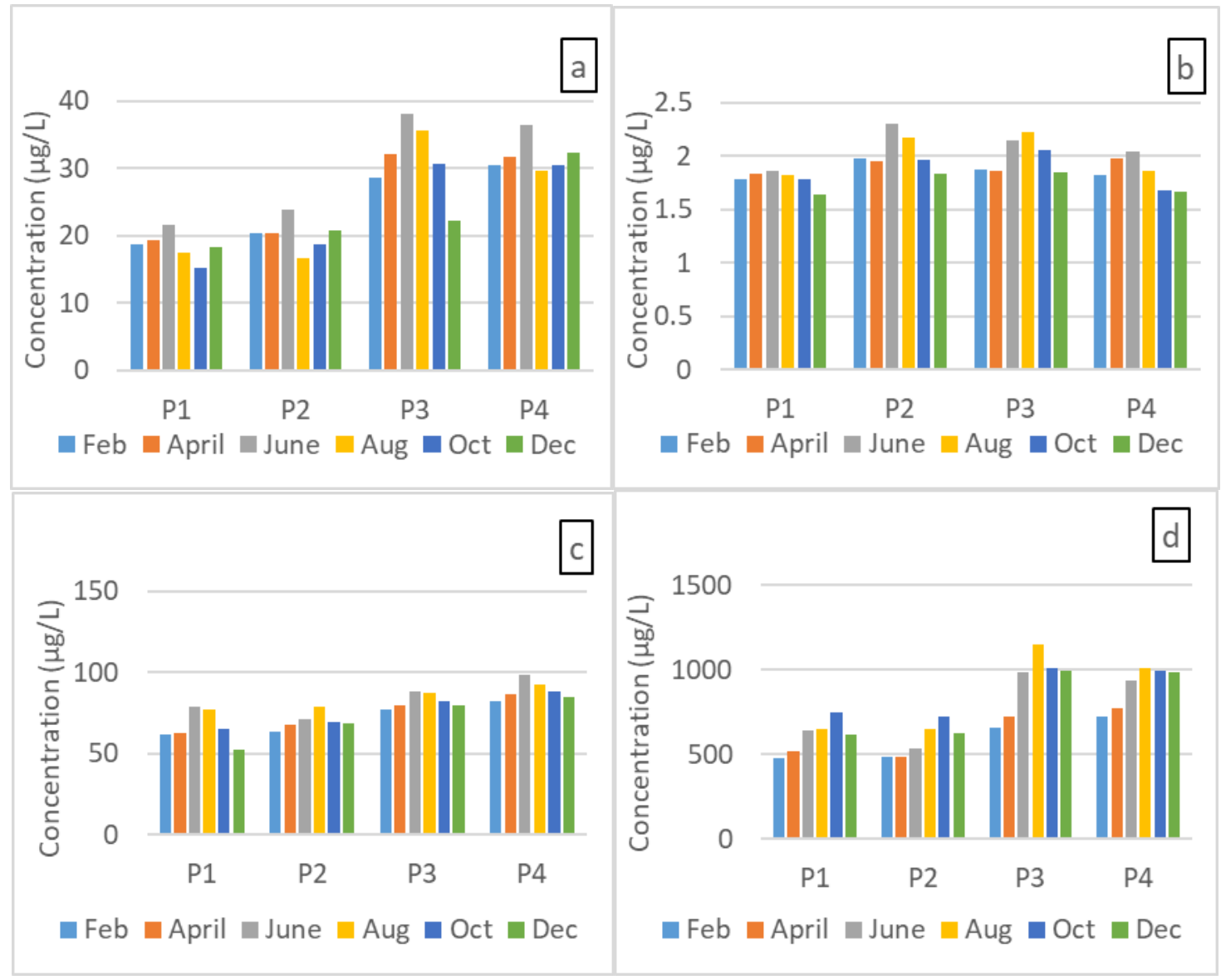

Fig. 2. Concentration of: a). Lead, b). Cadmium, c). Chromium and d). Nickel present at all sampling points during study period (in different seasons).

Table1. Comparison of metal concentration found in various river waters in world with the present study.

\begin{tabular}{|c|c|c|c|c|c|c|c|}
\hline Parameters* & $\begin{array}{c}\text { Ganga } \\
\text { river, } \\
\text { India [16] }\end{array}$ & $\begin{array}{l}\text { Indus river, } \\
\text { Pakistan [5] }\end{array}$ & $\begin{array}{c}\text { Balu river, } \\
\text { Bangladesh } \\
{[19]}\end{array}$ & $\begin{array}{c}\text { Po river, Italy } \\
{[20]}\end{array}$ & $\begin{array}{c}\text { Yangtze } \\
\text { river, China } \\
{[17]}\end{array}$ & $\begin{array}{c}\text { Mississippi } \\
\text { river, USA } \\
{[18]}\end{array}$ & $\begin{array}{c}\text { Malir river } \\
\text { (present study) }\end{array}$ \\
\hline Arsenic & - & $0.62-2.54$ & - & $0.58-2.11$ & - & - & $0.25-5.15$ \\
\hline Iron & $13.1-549$ & $12.0-154$ & $179.0-501.5$ & $1.0-11.6$ & 523 & 135 & $225.3-521.5$ \\
\hline Lead & $0.05-0.53$ & $13-160$ & $17.96-28.25$ & $0.09-1.17$ & 20.66 & 11.4 & $15.21-38.04$ \\
\hline Cadmium & $5-60$ & $10-22$ & $3-33$ & $0.10-0.59$ & 0.084 & 5.32 & $1.64-2.3$ \\
\hline Manganese & $20-140$ & $11-38$ & $28.28-730.8$ & $0.5-17.6$ & 229 & 97.4 & $45.78-210.19$ \\
\hline Cobalt & - & - & $4.05-53.42$ & $0.004-0.147$ & 0.47 & 5.72 & $7.05-33.92$ \\
\hline Nickel & $53-240$ & $61-253$ & $10.66-19.07$ & $0.44-4.32$ & 2.89 & - & $480.37-1153.41$ \\
\hline Chromium & - & $12-41$ & $4.05-8.44$ & - & 21.0 & 10.9 & $52.05-98.75$ \\
\hline Zinc & $5-290$ & $10-174$ & $8.39-76.86$ & $0.05-46.5$ & 25.0 & 28.3 & $2371.42-4213.2$ \\
\hline Copper & $3-33$ & $10-91$ & $3.81-19.99$ & $0.95-3.07$ & 7.31 & 31.5 & $292.48-1039.71$ \\
\hline
\end{tabular}

*All the units are in $\mu \mathrm{g} / \mathrm{L}$

Cadmium: Concentration of cadmium was generally low and only high concentration detected during month of June as $2.3 \mu \mathrm{g} / \mathrm{L}$ at Sampling point 2 (Noor Muhammad Goth) which was probably due to few scrap battery shops present in the area. Concentration of cadmium found in this study is lower than the values reported for Indus river, Pakistan, Balu river, Bangladesh, Ganga river, India and Mississippi river, USA (Table 1). Results show that the concentration of cadmium is within the maximum permissible limits provided by NEQS, US-EPA and WHO [12-14] as shown in Table 2. 
Table. 2. Comparison of some metal concentrations found in the present study with various standards.

\begin{tabular}{|c|c|c|c|c|}
\hline Parameters* & $\begin{array}{c}\text { WHO [12] } \\
\text { standard }\end{array}$ & $\begin{array}{c}\text { US-EPA } \\
{[13]} \\
\text { standard }\end{array}$ & $\begin{array}{c}\text { NEQS } \\
\text { standard [14] }\end{array}$ & $\begin{array}{c}\text { Malir river } \\
\text { (present study) }\end{array}$ \\
\hline Arsenic & 10 & 10 & 1000 & $0.25-5.15$ \\
Lead & 50 & 15 & 500 & $10.21-38.04$ \\
Cadmium & 10 & 5 & 100 & $1.64-2.3$ \\
Iron & 300 & 300 & 800 & $225.3-521.5$ \\
Zinc & - & 5000 & 5000 & $2371.42-4213.2$ \\
Copper & 1500 & 1300 & 1000 & $292.48-1039.71$ \\
Chromium & 50 & 10 & 1000 & $52.05-98.75$ \\
Manganese & 50 & 50 & 1500 & $45.78-210.19$ \\
Cobalt & - & - & 50 & $7.05-33.92$ \\
Nickel & - & 100 & 1000 & $480.37-1053.41$ \\
\hline
\end{tabular}

1: Drinking water standards; 2: Irrigation water standards; *All the units are in $\mu \mathrm{g} / \mathrm{L}$

Manganese: Generally, the concentration of manganese was low during the study period however, highest value of $210.19 \mu \mathrm{g} / \mathrm{L}$ was found during month of June at sampling point 3 (Allahwala Town). The lower values of manganese was found during September at sampling point 2 (Noor Muhammad Goth). The lowest value of 45.7 $\mu \mathrm{g} / \mathrm{L}$ was found during wet season August. Comparison in Table 1 reveal that manganese concentration in Yangtze river, China and Balu river, Bangladesh are higher than the Malir river's water. The maximum allowable limits given by WHO and US-EPA for manganese in drinking water is $50 \mu \mathrm{g} / \mathrm{L}$ and the permissible maximum concentration of manganese given by NEQS, Pakistan is $1500 \mu \mathrm{g} / \mathrm{L}$ (Table 2). Therefore, the concentration of manganese in the Malir river is higher than the allowable maximum limits provided by WHO and US-EPA however it is below NEQS limits which is irrigation water quality. So according to international standards pretreatment is required if using water for domestic purposes however, it can be use as irrigation water without treatment.

Cobalt: High concentration of cobalt was only detected during month of June which was $33.92 \mu \mathrm{g} / \mathrm{L}$ at the sampling point 4 (DHA Phase 7-Ext) which is higher than the Po river, Italy, Yangtze river, China (Table 1). Similarly, concentration of cobalt in the Mississippi river water, USA found to be $5.72 \mu \mathrm{g} / \mathrm{L}$ which is less than the current study. However, the concentration of cobalt found in Balu river, Bangladesh was $53.42 \mu \mathrm{g} / \mathrm{L}$ which is higher than the present study. The concentration of cobalt obtained in the present study is well below the irrigation water quality $50 \mu \mathrm{g} / \mathrm{L}$ provided by NEQS (Table 2). Therefore, at present the concentration of cobalt is not an immediate threat to the aquatic biota as well as for human health.

Nickel: Concentration of nickel during study period was consistently found at the higher side and ranges from 480.37 to $1153.41 \mu \mathrm{g} / \mathrm{L}$. High concentration of nickel $(1153.41 \mu \mathrm{g} / \mathrm{L})$ was found during month of August at sampling point 3 (Allahwala Town) and lowest concentration was $480.37 \mu \mathrm{g} / \mathrm{L}$ at sampling point 1 (Motorway M-9 intersection) during februry which was higher than all river water studies reported in Table1. The current study revealed that concentration of nickel is higher than the allowable limit of $100 \mu \mathrm{g} / \mathrm{L}$ provided by US-EPA and is also above the NEQS limit of $1000 \mu \mathrm{g} / \mathrm{L}$ for irrigation water quality (Table 2). This high concentration of nickel is possibly attributed to the presence of various vegetable ghee manufacturing factories located near sampling point 3 utilizing nickel as catalyst during ghee manufacturing process.

Chromium: Lowest concentration of chromium found at sampling point 1 (Motorway M-9 intersection) is 52.05 $\mu \mathrm{g} / \mathrm{L}$ during December and the highest value was $98.75 \mu \mathrm{g} / \mathrm{L}$ at sampling point 4 (DHA Phase 7-Ext) during June. Zhang and Kezhun [16] reported the concentration of chromium $21.00 \mu \mathrm{g} / \mathrm{L}$ in the Yangtze river which is lower than the studied value. Finding from all other studies in Table1 are showing lower values than the present study. Although it is high but still it is below the allowable limit of $1000 \mu \mathrm{g} / \mathrm{L}$ set my NEQS for irrigation water it can be used for agriculture purposes. However, results showing that concentration is above the limits provided by WHO $(50 \mu \mathrm{g} / \mathrm{L})$ and US-EPA $(10 \mu \mathrm{g} / \mathrm{L})$ which is necessitating the requirement for chromium removal from river water before any domestic use.

Zinc: The maximum concentration of zinc was observed during month of June (4213.4 $\mu \mathrm{g} / \mathrm{L})$ at sampling point 4 (DHA Phase 7-Ext) and lowest value of $(2371.42 \mu \mathrm{g} / \mathrm{L})$ was found to be during month of September at sampling point 1 (Motorway M-9 intersection). The value of zinc reported in the water samples of all studies reported in Table1 are lower than the present study. Current level of highest concentration of Zinc in Malir river is more 
than the concentration reported in Table 2 however, it is still below the limit provided by US-EPA and NEQS $(5000 \mu \mathrm{g} / \mathrm{L})$.

Copper: The concentration of copper found in the study is ranged from $292.48 \mu \mathrm{g} / \mathrm{L}$ during February at sampling point 1 and $1039.71 \mu \mathrm{g} / \mathrm{L}$ during June at sampling point 3 which is more than national standards (NEQS) but less than the international permissible standards provided by US-EPA and WHO. The maximum permissible limits provided by WHO, US-EPA and NEQS are $1500 \mu \mathrm{g} / \mathrm{L}, 1300 \mu \mathrm{g} / \mathrm{L}$ and $1000 \mu \mathrm{g} / \mathrm{L}$ respectively (Table 2). In the present study higher concentration of copper was observed which is higher than the values reported in the Indus river, Pakistan and other rivers reported in Table 1. Therefore, it is necessary to treat the river water for copper removal before any use.

\subsection{Overall Suitability of Malir River Water Quality for Irrigation Based on EC, TDS and SAR}

Values of EC and TDS are very important parameters in deciding the irrigation water quality. As shown in Table 3 that, the water quality can be classified based on the values of EC and TDS, from Class 1 to class 5. These classes are defined as; water is excellent, good, permissible, doubtful or unsuitable for irrigation use [21]. Similarly, according to environmental protection department of Alberta, Canada [22] irrigation water quality can be determined based on the EC and SAR values and it can be decided that water is safe, possibly safe or hazardous as irrigation water (Table 4). As shown in Table 3 the conductivity and TDS values of studied water $(915 \pm 10 \mu \mathrm{mho} / \mathrm{cm}$ and $565 \pm 10 \mathrm{mg} / \mathrm{L}$ respectively) are coming under 'Permissible' class of irrigation water (Class 3). Therefore, it shows that quality of water is permissible to use for landscape irrigation and plantation purpose and will not cause damage to the plant and soil.

Furthermore, SAR is an important quality parameter estimates the extent to which sodium ion present in the water would be adsorbed by the soil. If irrigation water having high SAR is applied to a soil for longer period, the sodium in the water can displace the magnesium and calcium in the soil matrix. Eventually it will decrease the ability of the soil to form stable aggregates and disrupt the structure of soil. This may also lead to a decline in permeation and infiltration capacity of the soil which will eventually results in inefficient crop production [23]. Therefore, SAR values are calculated for the Malir river water and presented in Table 4 with the allowable limits provided in Canadian Standards. It can be seen that the values of EC $((915 \pm 10 \mu \mathrm{mho} / \mathrm{cm})$ and SAR $(3.8 \pm 0.2)$ are within the safe range (i.e. $<1000$ and $<4$ respectively).

Table 3. Permissible limits for interpretation of water quality for irrigation [21].

\begin{tabular}{|c|c|c|c|c|c|c|c|}
\hline & & \multicolumn{5}{|c|}{ Classes of Water } \\
$\begin{array}{c}\text { Potential } \\
\text { Irrigation } \\
\text { Problem }\end{array}$ & Units & \multirow{2}{*}{$\begin{array}{c}\text { Present } \\
\text { Study }\end{array}$} & & \multicolumn{6}{|c|}{\begin{tabular}{c} 
Class 1. \\
\cline { 4 - 8 }
\end{tabular}} & & $\begin{array}{c}\text { Class 2. } \\
\text { Gocellent }\end{array}$ & $\begin{array}{c}\text { Class 3. } \\
\text { Permissible }\end{array}$ & $\begin{array}{c}\text { Class 4. } \\
\text { Doubtful }\end{array}$ & $\begin{array}{c}\text { Class 5. } \\
\text { Unsuitable }\end{array}$ \\
\hline $\begin{array}{c}\text { Electrical } \\
\text { Conductivity }\end{array}$ & $\mu \mathrm{mho} / \mathrm{cm}$ & $650 \pm 10$ & 250 & $250-750$ & $750-2000$ & $2000-3000$ & 3000 \\
\hline TDS & $\mathrm{mg} / \mathrm{L}$ & $450 \pm 10$ & 175 & $175-525$ & $525-1400$ & $1400-2100$ & 2100 \\
\hline
\end{tabular}

Table 4. Comparison of SAR and EC values of studied wastewater with the irrigation water guidelines in Alberta, Canada [22].

\begin{tabular}{|c|c|c|c|c|c|}
\hline Parameters & Present Study & Safe & Possibly Safe & Hazardous \\
\hline EC $(\mu \mathrm{mho} / \mathrm{cm})$ & & $915 \pm 10$ & $<1000$ & $1000-2500$ & $>25000$ \\
\hline SAR & & $3.8 \pm 0.2$ & $<4$ & $4-9$ & $>9$ \\
\hline
\end{tabular}

\section{CONCLUSIONS}

Discharge of wastewater from industries as well as domestic activities into the Malir river has augmented the pollution and is serious threat to the environment and public health. Present study provides a comprehensive overview on the concentration of studied metals at upstream and downstream of Malir river, Pakistan. Study revealed that the concentration of iron, copper and nickel is most of the time higher than the other studied metals. Highest concentration of iron was found at sampling point 3 (Allahwala Town) sampling point in the Malir river 
and it was found that the level of iron and manganese was considerably high during study period and exceeded the allowable limits provided by WHO and US-EPA however, it was meeting the NEQS limits. The contamination of river water with the studied metals is varying depending to the nature of the sites and the intensity of the industrial and agricultural run off. However, relatively high concentration of pollutants were observed during dry season April to June. While lower concentrations were observed during wet season July to September. Results obtained showing variability with respect to the location as well as time of year which probably depending on the natural as well as anthropogenic conditions. Generally, downstream quality of Malir river is inferior than the upstream quality. Only concentration of nickel $(2371.42-4213.2 \mu \mathrm{g} / \mathrm{L})$ was above the allowable limit for irrigation water quality $(1000 \mu \mathrm{g} / \mathrm{L})$ which is probably attributed to the discharge of effluent from vegetable ghee manufacturing factories working in the vicinity. However, it is expected that the quality deterioration may continue with time. There is an urgent need to control the discharge of untreated industrial effluents to protect the public health and environment. Study revealed that the overall suitability of Malir river water for irrigation, based on Electrical Conductivity (EC), Total Dissolved Solids (TDS) and Sodium Adsorption Ratio (SAR) is ranked as Class 3 (Permissible) and possibly safe for irrigation according to Environmental Protection Department of Alberta classification. Study shows that the Malir river water at the study sites is safe for landscape irrigation and plantation however needs proper treatment if using for domestic purposes. Furthermore, the insight obtained is of great importance for planning and sustainable management of available water resources in the region.

\section{REFERENCES}

[1] Shahbaz, M., Lean, H.H., Does financial development increase energy consumption? The role of industrialization and urbanization in Tunisia, Energy Policy, vol. 40, no. 1, 2012, p. 473-479.

[2] Wang, Y., Wang, P., Bai, Y., Tian, Z., Li, J., Shao, X., Li, B.L., Assessment of surface water quality via multivariate statistical techniques: a case study of the Songhua River Harbin region, China, Journal of HydroEnvironment Research, vol. 7, no. 1, 2013, p. 30-40.

[3] Wei, B., Yang, L., A review of heavy metal contaminations in urban soils, urban road dusts and agricultural soils from China, Microchemical Journal, vol. 94, no. 2, 2010, p. 99-107.

[4] Saleem, M., Wastewater reuse potential in Pakistan: Guidelines for environment and public health protection, International Journal of Environmental Engineering, vol. 1, no. 3, 2009, p 306-320.

[5] Jaleel, T., Asraf, M., Jaffar, M., Afzal, M., Population status of the Indus River, Pakistan, through heavy metal and micronutrient content offish, sediment and water, Water Research, vol. 30, no. 6, 1996, p. 1337-1344.

[6] Rahman, A., Lee, H.K., Khan, M.A., Domestic water contamination in rapidly growing megacities of Asia: case of Karachi, Pakistan, Environmental Monitoring and Assessment, vol. 44, no. 1-3, 1997, p. 339-360.

[7] Saleem, M., Hussain, A., Samo, S.R., Contribution of S.I.T.E. area drainage system of Karachi in polluting the Lyari River, 3rd National Energy Resources of Pakistan: Potential, Utilization, Conservation and Impact on Environment at Quaid-e-Awam University of Engineering, Science and Technology, Nawabshah, March 18-20, 2010.

[8] Saleem, M., Essa, M.H., Suitability for sustainable reuse of secondary effluent: A case study in Saudi Arabia, NED University Journal of Research, vol. 4, no. 1, 2010, p. 23-34.

[9] http://www.google earth.com (15.01.2020).

[10] APHA (American Public Health Association), 2000. Standard methods for the examination of water and wastewater, Washington, D.C.

[11] Chang, C., Sommerfeldt, T.G., Carefoot, J.M., Schaalje, G.B., Relationship of electrical conductivity with total dissolved salt and cation concentrations of sulfate-dominate soil extracts, Canadian Journal of Soil Science, vol. 63, no. 1, 1983, p. 79-86.

[12] World Health Organization (WHO), Guideline for drinking water quality, 3rd edition, vol. 1, Recommendation Geneva, 2008.

[13] US-EPA. 2011. Standard for drinking water, http://water.epa.gov/ (15.01.2020).

[14] National Environmental Quality Standards (NEQS), 1997. National environmental quality standards for municipal and liquid industrial effluents', www.punjab.gov.pk/epa/indus.html. (12.6.2019).

[15] DFID (Department for International Development), UK, Groundwater studies of arsenic in Bangladesh, Final report, Dhaka. BGS, Technical Report WC/00/19, vol. 1, 2000.

[16] Aktar, M.W., Paramasivam, M., Ganguly, M., Purkait, S., Sengupta, D., Assessment and occurrence of various heavy metals in surface water of Ganga river around Kolkata: a study for toxicity and ecological impact, Environmental Monitoring and Assessment, vol. 160, no. 1-4, 2010, p. 207-213.

[17] Zhang, L., Kezhun, Z., Background values of trace elements in the source area of the Yangtze river, The Science of the Total Environment, vol. 125, no. 1, 1992, p. 391-399. 
[18] Boyd, C.E., Walley, W.W., Total alkalinity and hardness of surface waters in Alabama and Mississippi. Alabama Agricultural Experiment Station Bulletin, no. 465. Birmingham, Ala: Auburn University Press. 1975.

[19] Islam, M.Z., Noori, A., Islam, R., Azim, M.A., Quraishi, S.B., Assessment of the contamination of trace metal in Balu River water, Bangladesh, Journal of Environmental Chemistry and Ecotoxicology, vol. 4, no. 14, 2012, p. 242-249.

[20] Pettine, M., Camusso, M., Soluble and particulate metals in the Po river, Italy, Factors affecting concentrations and partitioning, The Science of the Total Environment, vol. 145, no. 1, 1994, p. 243-251.

[21] Fipps, G., Irrigation water quality standards and salinity management, Texas A\&M University, Cooperative Extension, Technical Bulletin B-1664. vol. 2, no. 1, 2004, p. 214-227.

[22] AEP (Alberta Environmental Protection), Guidelines for municipal wastewater irrigation, municipal program development branch environmental sciences division, Environmental Services, Report No. T-528, Alberta, 2000.

[23] Dontsova, K.M., Clay dispersion, infiltration, and erosion as influenced by exchangeable Ca and Mg, Soil Science, vol. 167, no. 1, 2002, p. 184-193. 